\title{
Directives in Sinhala: Children's Speech and Adult Child-Directed Speech
}

\author{
L. Abesooriya ${ }^{1}$ and K. Perera ${ }^{2 *}$ \\ ${ }^{1}$ Department of English Language Teaching, University of Kelaniya, Sri Lanka \\ ${ }^{2}$ Department of English, University of Colombo, Sri Lanka
}

\begin{abstract}
Directives is an important area of study in child language development and language socialization since it illustrates children's ability to affect the behavior of others around them by using language. However, we have no account of directives by children in Sinhala. A study of Sinhala directives by children is important given that research on diverse languages contribute to significant changes in our knowledge of both the typology and the linguistic resources used for directives in general. The main aim of this study is to record the forms of directives used by children speaking Sinhala as a first language. Sinhala, the dominant language of Sri Lanka, is little studied in terms of pragmatics. Therefore, a secondary purpose of this study is to contribute to the knowledge of Sinhala pragmatics. Using recorded data and observation from children and their caregivers, this paper studies the use of Sinhala directives by middle class children and their adult caretakers in Sri Lanka. The study shows that children from 2-4 years of age are able to use directives appropriate to their pragmatic function. It also shows surprising findings on children's use of (im)polite language, an area that needs more research.
\end{abstract}

Keywords: child-directed speech, directives, child language development, politeness, Sinhala

\section{Introduction}

Being able to instruct others is an important part of human communication. Languages are very diverse in how this form of communication is affected. They assign different features for the formation of directives, or the speech act used to direct something. How do Sri Lankan children, speaking the majority language Sinhala, use directives? How do adults use directives in child directed speech? In this paper, we explore the use of Sinhala directives by children and their caretakers in their home settings. Through the presentation of children's polite and impolite

* Correspondence should be addressed to Dr. K. Perera, Department of English, University of Colombo, Colombo, Sri Lanka

Email: kaushalya@english.cmb.ac.lk

https://orcid.org/ 0000-0002-6632-9912

(Received 25th May 2019; Revised 21st June 2019; Accepted 24th June 2019) (C) OUSL 
use of directives as well as caretakers' directive use, our aim is to contribute to the field of pragmatic development in children, especially in Asian contexts.

A secondary aim of this paper is to contribute to cross-linguistic research on directives by presenting an array of Sinhala linguistic features that are used to form directives. Despite the attention given to directives in North America and Europe, studies of directives in Asian contexts are uncommon, with only one study that we know of (Fedricks, 2012) on a Sri Lankan language, in this case Sinhala.

In the following section, we define directives and present the current status of literature on directives, including studies done in Sri Lanka. In this same section, we also synthesize work on children's acquisition of directives. In the third section, we outline our research design and provide a description of our method and data. Following this, we present the findings of our study, which includes a description of directives in Sinhala, a brief discussion of (im)politeness in relation to this, and an analysis of directives usage by the children and caretakers in our study.

\section{Review of Literature}

In this section we provide a review of the relevant literature, in two sections. The research on directives and the research on child language development are largely separate but overlap in some instances. Therefore, we draw on both areas of study here.

\section{Directives}

Directives have been a productive area of linguistic research since the work of J. L. Austin and John Searle, resulting in a debate on the definition of directives in later research. The most basic definition of a directive is that they are "attempts... by the speaker to get the hearer to do something" (Searle, 1975, p.355; also see Clark, 2009, p.292). In Searle's (1975) list of directives, he includes commands, requests, questions, appeals and pleas, challenges, permission and advice as well as dares and defiance. Despite agreement on the general definition, however, the precise definition of directives is still debated by scholars. The main issue at stake appears to be the question whether the imperative - the canonical form of a directive - is the only type of directive, or whether 'indirect' attempts at making a hearer do something is also a directive (Curl and Drew, 2008). We understand directives to be a broad category, adhering to the job of 'getting something done' (Searle, 1975).

An early and long-standing understanding that indirect directives are more polite than 'explicit' directives has been challenged in recent years (Watts, 2003 as cited in Curl and Drew, 2008). It is generally true of directives in English where the more indirect directive is used for politeness (Craven and Potter, 2010; Curl and Drew, 2008). In an early study of directives in American English, Susan Ervin-Tripp, (1976) named five types of directives: statements on need, imperatives, imperatives embedded in other syntactic forms such as questions, permission directives, directives structured as questions, and hints. Additionally, Ervin-Tripp discussed multiple social variables that affected the choice of directives, some of these being 
hierarchical relationships, familiarity, and presence of outsiders. However, Weigel \& Weigel's (1985) study of directives in the "primarily black male migratory agricultural laborer subculture" of Eastern United States (p.65), an attempt to test Ervin-Tripp's classification of directives, contradicted Ervin-Tripp's findings. In it, the participants showed a high number of imperative usages disregarding the social and work constraints that would have been expected by the findings of the prior study. Taken together, these two studies show the need to study directives usage across contexts even when it is the same language.

Studies on different languages have provided both context-related and languagerelated findings. Rossi's (2012) study on Italian shows that directives and requests for action differ according to the project (course of action undertaken together) and ownership, i.e. whether the course of action is felt to be undertaken individually or jointly. In Greek, imperatives used as directives are widespread, and are made acceptable by the existence of linguistic features that indicate not only command (which an English imperative does) but also wishes and desires (EconomidouKogetsidis, 2002). Additionally, while Ervin-Tripp has not discussed positive and negative imperatives separately, some scholars do so (e.g. Weigel and Weigel, 1985). Similarly, studies on Nepalese and Japanese data show that different linguistic forms (e.g. modals) can be used to vary the intensity of directives (Upadhyayi, 2003 cited in Fedricks, 2012; Takada, 2013). Evidently, languages use a variety of linguistic features alongside directives to affect their politeness and directness, and these two aspects do not necessarily contradict each other. In other words, directness in directives does not always imply impoliteness. These studies are especially relevant to the study of languages in which morphological forms signal directives and politeness separately, as we will show in our research.

In relation to Sinhala, the sole study we are aware of is Fedricks' (2012) study of directives in a Buddhist temple setting in the USA. Federicks used a classification system that included ten types of directives. These included eight from Ervin-Tripp and Upadhyayi as well as two new types (epistemic directives and zero verbal directives) arising from his own data. Fedricks shows that women used suggestion directives more, and used less imperatives than men, who used question directives more. Our study extends this work by exploring a different setting - the home setting, which is a linguistic domain that is expected to show informal directive usage. Fedricks (2012) and other Sinhala scholars (Ch. Premawardhena, 2007; Chandralal, 2010) also mention the verbal suffix $-k o$ as a feature used with imperatives for politeness and for persuasion. Our study illustrates counterexamples to this which we will discuss later.

\section{Children and directives}

A large body of research exists on child language acquisition (CLA), also called first language acquisition (FLA), a dynamic area of study for many decades in linguistics (Ferguson and Farwell, 1975), psychology (MacNamara, 1972) and in anthropology where it is studied as part of language socialization (Duranti et al., 2012). Much of this early research has been in monolingual settings of language acquisition, either of English or other languages. This study adds to the current trend in researching 
child language development in bilingual settings, given that even in generally bilingual settings individual families can show variation in this.

Since the 1970s, there has also been much research on children's pragmatic development (Cameron-Faulkner, 2014; Hollos and Beeman, 1978; Zufferey, 2016). This includes their ability to respond to others and produce various speech acts, such as directives. Two areas of linguistics have produced research on directives developmental studies and studies of (im)politeness, both bodies of research relevant to our study. This body of research is cross-linguistic in nature (Matthews, 2014), a necessary addition to research in directives given the diversity of languagespecific forms of directives. Our study adds to this.

Research on children's development of language abilities has shown that language approximating a directive, or an order for an adult to do something, emerges in the child at about 10 months of age; conventional directives appear at around 20 months, or a little over 2 years of age (Matthews 2014). Children find it "easier to make certain requests (ask, order, forbid) than to allow something or to make a promise about something" (Clark 2009, p.302). Therefore, children may use a higher number of directives than adults, which makes directives a productive locus of study for CLA. However, assigning illocutionary force to children's utterances is at times difficult and should be done with care in very young children (CameronFaulkner, 2014). Thea Cameron-Faulkner (2014) calls for more research that takes into account the context and co-participants who are involved in speaking, along with the children themselves.

Such contextual work has been done in the culturally and linguistically diverse area of (im)politeness research Küntay et al. (2014) and Duranti et al. (2012) define politeness as ways of maintaining social and communicative concord and avoiding social discord. Further, Brown and Levinson (1987) define politeness as showing awareness of another person's public self-image, or face, for example, by avoiding imposition on others or showing solidarity with others. For instance, Clark (2009) positions "Come here" as a less polite directive whereas "Could you come here?" as a more polite directive. Matthews (2014) states that politeness vary according to factors such as speaker-hearer characteristics (e.g., age, degree of familiarity), context (e.g., level of formality), and topic of conversation. Even though different languages require different grammatical forms to express directives, cross-linguistic studies have shown that children generally seem to acquire the pragmatic function of directives early and they "are sensitive to contextual factors such as activity type and age of interlocutor and vary the level of politeness accordingly" (Küntay et al., 2014, p.325; Zufferey, 2016). In an early cross-cultural study, Hollos \& Beeman (1978) found that Norwegian and Hungarian children differed in their communicative styles when using directives, with Hungarian children being more direct and Norwegian children being more indirect. Contrary to previous research which showed that girl children were more indirect and therefore more polite in play, and boy children were the opposite of this, Aronsson and Thorell (1999) have shown that children of both sexes delighted in playing conflict situations. They also showed that children used directives to perform invitations, or even as dares or 
threats showing multiple pragmatic functions as used by children. Despite the accumulation of research in different languages, research on bilingual children acquiring directives in both languages is still scarce.

Research on CLA in Sri Lanka is sporadic. An early paper by James W. Gair and colleagues (Gair et al., 1998) continues to be the most robust. In a series of studies, they tested Universal Grammar (UG) principles by studying the acquisition of Sinhala by a large group of children, concluding that children mapped the spoken languages they heard to the underlying control structures they had acquired. More recent studies in child-related language come from the field of speech and communication disorders. One such study by Hettiarachchi and Ranaweera (2013) illustrate the use of multisensory storytelling to enhance vocabulary development in children who have language-learning difficulties and discusses possibilities of increased skills in communication in this manner. In a study of the acquisition of Sinhala case marking by 37 children Silva (2002) found that children acquired Sinhala case marking as a cluster (rather than separately) and that no difference in acquisition was noted due to gender or regional differences. Children in Silva's study were able to produce directives by 1.8 years of age. This ties in with findings on the early production of directives in children of other linguistic environments (Matthews 2014). As is evident, there is a pressing need for child-language acquisition studies in Sri Lanka.

\section{Methodology}

Many of the studies in child language acquisition have used elicitation techniques or improvisations to collect data (Aronsson and Thorell 1999; Gair et al., 1998), whereas research in language socialization uses naturally occurring data. Similar to the latter, this study uses a qualitative research design which includes recordings of naturally occurring interaction and observations.

The participants of this research were purposively selected. Five children from five middle class families from the first author's neighborhood in Kandy, the main city of the Central Province of Sri Lanka. The families were considered middle-class due to parental occupation (professional) and access to English (at least one parent spoke English). We will name the families A, B, C, D and E. They were all female children between the ages of two to four years.

The first author initially approached the families to research bilingual families with the prospect of studying Sinhala-English bilingual children and chose two families for extended observation. During an initial meeting with the first author, the mothers of the children stated that the families were bilingual. However, the use of the two languages varied in the families and the children did not speak in English during observation. Only family E was observed to be bilingual; in families $\mathrm{C}$ and D, the fathers spoke to the children only in English whereas the mothers spoke to 
them in Sinhala and English, with varying extents of codeswitching. ${ }^{\dagger}$ In family D, the father did not spend much time with the children due to his work schedule, which entailed travelling regularly to other parts of the country, and spent only weekends with the child who then had less exposure to English. Similar to father $\mathrm{D}$, father B also worked outside the region. The fathers in families $\mathrm{E}$ and A travelled to work daily whereas the mothers were homemakers. Some families lived with extended family members, which included grandparents. The primary caretakers mothers and grandmothers - used mostly Sinhala in their interaction with the children.

Data was collected over a period of a month. Initially, the caretakers undertook to self-record children's everyday speech. However, this was not successful as the primary data collection method due to the caregivers being pressed for time as well as, in some instances, their lack familiarity with technology. The first author then audio recorded the interactions during her observations in two of the households; the notes taken during observations were also written into field notes. The children were observed during their meal times and their play times with other children. We analyze approximately 570 minutes (i.e. 9.5 hours) of spoken data and 20 minutes of self-recorded interaction by the families. The speech samples were coded for types of directives and their functions, and then compared to the categorization by Ervin-Tripp (1976) and Fedricks (2012). When coding for (im)politeness suprasegmental features such as pitch and intonation were taken into consideration. We will not, however, discuss suprasegmental features in this article.

\section{Findings and Discussion}

In this section, we first present a classification of directives of the Sinhala language as found in our data. Following this, we present a brief discussion of forms of (im)politeness relating to directives, where we challenge the current understanding of one form. Finally, we present our findings on directives use.

\section{Form and function of directives in Sinhala}

This section includes a discussion of the classification of directives and examples of directives found in our data. We have used the classification of directives by ErvinTripp (1976) and Fedricks (2012) as the basis for our classification. However, our data does not include the following categories of directives: elliptical directives, epistemic directives and zero verbal directives. $¥$ This absence could be due to the

†Codeswitching is here defined as the alternation of codes both between speakers' turns or within a turn (Wardhaugh, 2011).

¥ Elliptical directives have a noun or verb missing (e.g. tawa dekak, meaning 'two more'); epistemic directives use epistemic adverbs such as hithanawa (e.g. mama hithanne obo wahanse meheto wadinawa, meaning 'I think you come here most honoured sir'); zero verbal directives where no conversation takes place but action is directed by contextual knowledge and non-verbal communication such as gesture (e.g. long pause used to indicate 
particular nature of interaction we observed, which is that of children interacting with each other, or interacting with adult caretakers. We have left out two categories - 'permission requests' and 'questions as directives. In our data, requests are not made for the purposes of obtaining permission; neither is the question form used for queries. Therefore, question forms are absorbed into other categories, depending on their function as directives. Our data also included two types of directives not mentioned in Ervin-Tripp (1976) and Fedricks (2012). These are predictions and conditions which function as directives.

Next, we will provide examples of each type of directive found in our data. In most instances, we show the directives used by children, except in the case of directive types that have only been used by adults. Children in the study are identified by the alphabetical letter correlating with the family. In some cases, children show developmental errors in terms of phonology, which are marked by an asterisk (we discuss these later).

\section{Need statements}

\begin{tabular}{|c|c|c|}
\hline [1] Child C: & $\begin{array}{l}\text { Bittora } \\
\text { eggs }\end{array}$ & $\begin{array}{l}\text { witorak } \\
\text { only }\end{array}$ \\
\hline
\end{tabular}

While Fedricks (2012) identifies three verbs for the expression of need (o:ne, o:ne karanawa, o:ne wenawa), in our data we find only o:ne (want). In this situation, the child expresses a need for eggs, which then functions as a directive to be given eggs. It is probable that Fedricks' research setting, a temple, produced more variations of o:ne due to extensive politeness constraints that exist in such a setting, whereas such an array may not be necessary for the children in the home domain.

\section{Imperatives}

We note two variations in imperatives: imperatives to act, as well as imperatives to refrain from acting.

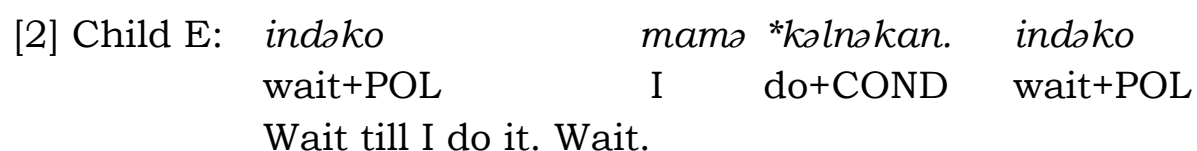

In this situation, the child wants to do an action herself, and commands the playmate to wait until she does it. This functions as an imperative. As Fedricks (2012) states, Sinhala directives add - $k$ o to indicate that it is a polite form (glossed for now as POL) or for persuasion. Here, $-k o$ is added to the verb indako for persuasion.

lay people to take the lead in prayers). Definitions, examples and translation are from Fedricks (2012, pp.35-36). 
The third example is an imperative to refrain from an action.

$\begin{array}{llll}\text { [3] Child B: } & \text { epa } & \text { oya } & \text { enda } \\ \text { don't } & \text { you } & \text { come } \\ \text { Don't come } & & \end{array}$

In this situation, the child commands her playmate not to come. In Sinhala, the quasi-verb epa is added to the verb to indicate that the action should not be done, classified as negative imperatives by Chandralal (2010).

Additionally, a negative imperative can also be formed by æti, another word which Gair and Paolillo (1997) classify as a quasi-verb (uninflected for tense, p.26), as in example 4:

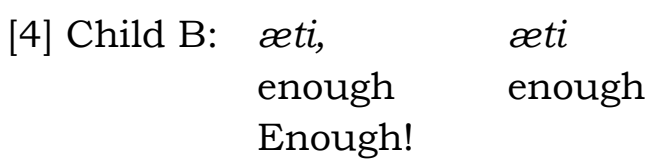

Here, the child states that she has had enough food and she does not want any more. This is again a negative imperative, since she is indicating that she should not be given more food; it is also a refusal to eat more. Of note is the fact that in itself, æti is not a negative and can function both as positive (to mean yes, I have enough') or negative, as in the above example.

\section{Hints}

[5] Child E:

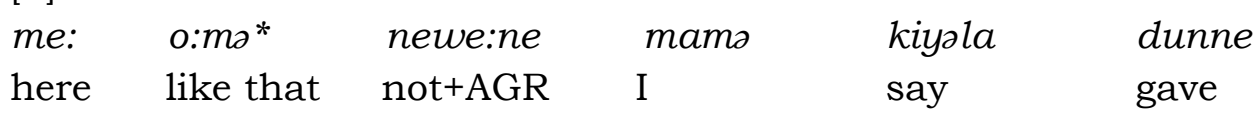

Hey, that is not how I taught [you to do it].

In this instance, the main proposition of this statement by the child is that the playmate is not acting according to instructions. By saying this, she implies that the addressee has not followed directions correctly. The child is expecting an active response from the listener, for the action to be done her way, which makes it a directive. In the next example, Child $\mathrm{D}$ is showing another child how to do something. 
[6] Child D: me:ma *galanne
this way removes FOC
This is how you remove [it].

Ervin-Tripp (1976) includes statements of condition as the example for this category [6], which we also note in our data. We observe that both examples are more than hints, since [6] is actually a demonstration of an action, which can be considered a directive.

\section{Suggestives}

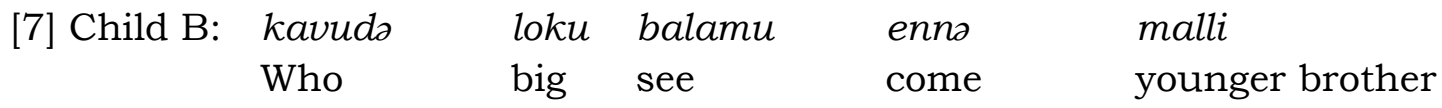

Let's see who is taller, younger brother

In this occasion, the child suggests that her playmate, a younger boy, should join her so that they can measure their heights and conclude who is taller. Since Sinhala is a pro-drop prone language, the subject is missing in this but is made clear by the verb ending with the morpheme $-u$ (first person plural). This confirms Fedricks' (2012) finding that suggestives are used as directives for collaborative action.

\section{Requests}

Our classification of requests is somewhat different to the classifications by Fredericks and Ervin-Tripp. Both scholars have a category termed permission directive, which include some requests. However, in our data, requests were not used to ask for permission; at the same time, the data does not include permission requests. The form of the requests is typically the question form (but not all questions are requests).

[8] Child A: athona innæ:

there stay+Q

Stay there, ok?

In this instance, the child needs the listener to wait for her at a particular place. The verb inno is coupled with -æ: an agreement marker when ending a verb, and in rapid speech the neutral vowel ending of the verb is elided. The addition of -æ: transforms the imperative verb form into a request because it makes it more polite and seeks agreement to the imperative.

[9] Child B: $\begin{aligned} & \text { mage pænsals dennoko: } \\ & \text { my } \\ & \text { Give (me) my pencil. }\end{aligned}$

Here, the child asks her playmate to give her pencil back. The verb is in the canonical form of the imperative - denno. However, the addition of - $k o$ adds a 
persuasive element to it, which makes it a request similar to 'can you please give me the pencil?' rather than a direct imperative.

\section{Refusals}

In our data, refusals come in two forms. The first form includes the quasi-verb bæ: (cannot) as in example 10.

[10] Child D: athin kannə bæ:
hand+INS eat cannot
I can't eat with my hand

Here, the child's refusal to eat by hand also acts as a directive that she should be fed by her mother. The mother understood is as such. However, not all refusals are directives and the function is context-bound, like most other forms.

The following three types of directives are only found in adult speech. For convenience, we remind the reader again that 4.1.8 and 4.1.9 are newly formed categories necessitated by our data.

\section{Embedded imperatives}

[11] Mother C:

$\begin{array}{llllll}\text { akkits } & \text { kiyanno } & \text { me mona:th } & \text { ekkado } & \text { kanne } \\ \text { elder sister+DAT } & \text { tell } & \text { this what+also } & \text { with+Q } & \text { eatFOC }\end{array}$

Tell the elder sister what she will eat this with.

In this situation, the mother wants the child to explain to her older sister what curries accompany the rice. The utterance begins with the directive kiyanno (an imperative) which is followed by the content of what needs to be conveyed.

\section{Prediction}

[12] Mother D: baba: dæen do:ni wage: duwsnəwa:

baby now Doni like run

Now you (the baby) will run like Doni

In this example, the mother predicts that the child will run like Doni, a character in a popular television series, to come and eat her food. The verb duwsnawa: is used in the present tense, which is also used for the future and for predictions in Sinhala. This is an indirect directive, acting as an imperative for the child to eat. We have two such directive forms, both by adults, to convey expected action to the children.

\section{Condition}

\begin{tabular}{|c|c|c|c|}
\hline $\begin{array}{r}\text { [13] Mother D: jo:dato } \\
\text { joda+DAT }\end{array}$ & $\begin{array}{l}\text { ice } \\
\text { ice }\end{array}$ & $\begin{array}{l}\text { ekak } \\
\text { one }\end{array}$ & $\begin{array}{l}\text { genath } \\
\text { bring }\end{array}$ \\
\hline
\end{tabular}
[I] will bring Joda an ice cream. 
Here, the mother somehow wants to feed the child. Hence, she makes a 'deal' that she will buy her an ice cream if child $\mathrm{D}$ eats her food. The little girl is addressed by a pet name, Joda (taken from a well-known character of a local television series). The conditional statement acts indirectly as a directive to eat, which is the only condition under which the child gets her ice cream.

\section{Development of directive forms in children}

While the syntactic form of the directive is correct in the language produced by the children in this study, in some instances we note developmental errors in phonology. In example [2], indəko mama *kalnəkan (wait till I do it), the child does not produce the $/ \mathrm{r} /$ in the verb /kərənə/, replacing it with $/ 1 /$. We also find replacement of /r/ with /s/ in / saumak/ in loku: saumak hadanno (make a large circle), and replacement of $/ \mathrm{m} /$ with /p/ in / pats/ in pats bæ: (I can't). Other such developmental errors found above are: omission of $/ \mathrm{r} /(/$ witaak/) [example 1], omission of /h/ (/me:ma/) [example 6] and omission of /w/ (/galanne/) [example 6]. While not directly relevant to the study of directives, we present these as a contribution to the discussion of child language development in Sinhala.

\section{Politeness in directives}

This section presents our findings on the use of polite and impolite forms of directives, including a description of the use of the morpheme $-k o$ in its use as an intensifier.

\section{Verbal forms of (im)politeness}

In the presentation of the structure of directives so far, we have shown the canonical forms of the directive, which is also counted as the polite form. Unlike English, and similar to languages such as Korean (Byon, 2006) and Japanese (Geyer, 2018), Sinhala expresses (im)politeness in directives through verbal morphology and affixation.

The canonical form of the directive is the imperative, for which Sinhala uses the infinitive form of the verb (Chandralal, 2010, p.254). Examples for this are kiyanno (tell), and kanno (eat). In Sinhala, however, as we saw above (4.1.4), directives can also use the verb's first-person plural form (e.g., kamu) and other morphemes as seen above. In terms of politeness, the imperative can be considered the most direct form of the directive, whereas suggestives, conditions, and predictions can be considered indirect and at the same time, more polite forms of the directive.

At the same time, Sinhala also has an impolite form of the verb. For this, Sinhala uses the present tense form of the verb (ending in $-w a$ ). An example is given below:

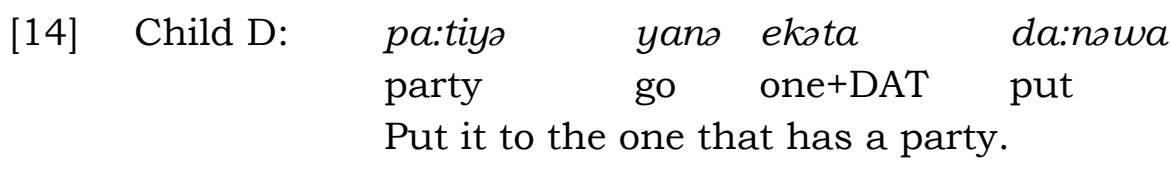

Here the child orders the sibling to switch to the television channel that is showing a party. In this, the verb form used is da:nəwa (put), derived from da:nno. In this 
impolite version of the imperative form, the verb is shortened and verb-final -wa is added. This greatly adds to the force of the imperative, making it a peremptory order.

\title{
2. The morpheme -ko and (im)politeness
}

The morphological feature $-k o$ has generally been typified as a politeness or persuasive marker in Sinhala (Fedricks, 2012). This is, however, misleading. We present a reinterpretation of this feature, classifying it as an intensifier (glossed from now on as INT) as shown through the two examples below. As an intensifier it enhances the polite and impolite forms of the imperative used.

\section{a) -ko with the canonical form of the imperative}

When - $k o$ is used with the canonical form of the directive - the imperative - it adds an element of entreaty or persuasion to the imperative.

\author{
[15] Child D: dennako dennako \\ give+INT give +INT \\ Give it, please! Give it, please!
}

Here, the verb does not contain any features that indicate extra politeness but neither is it impolite even without the $-k o$. However, the $-k o$ form adds a persuasive element to the verb, and together they form what could be termed a request.

\section{b) -ko with the impolite imperative}

In the example below, the same verb shown in (a) above is seen with the morpheme $-k o$, but this time with the impolite form of the verb.

\section{[16] Child D: denawako \\ give IMP+INT \\ Give it! (rudely)}

Here, the child asks for something from the brother, using the impolite imperative (denawa), to which the $-k o$ is added. -ko does not neutralize the impoliteness but instead intensifies the force of the imperative. Given that it is added to the impolite form of the imperative, we argue that $-k o$ is not a politeness marker as classified in prior literature, but is an intensifier used for persuasion: it intensifies the force of the verb, regardless of whether it is in the polite or impolite form.

\section{Use of directives by children and adults}

In this section, we analyses how directives are used by both the children and the adults in our study. This includes an analysis of the types of directives used by each group as well as a more detailed analysis of the children's use of directives. Table 1 provides the number and type of directives used. 
Table1. Types and Number of Directives Used by Participants

\begin{tabular}{|l|c|c|c|}
\hline & Child & Adult & Total \\
\hline Need & 1 & 1 & 2 \\
\hline Imperative & 28 & 42 & 70 \\
\hline Embedded Imperatives & 0 & 1 & 1 \\
\hline Hints & 3 & 1 & 4 \\
\hline Suggestives & 5 & 2 & 7 \\
\hline Requests & 12 & 18 & 30 \\
\hline refusal & 1 & 0 & 2 \\
\hline Predictions & 0 & 2 & 2 \\
\hline conditions & 0 & $\mathbf{6 9}$ & $\mathbf{1 1 9}$ \\
\hline Total & $\mathbf{5 0}$ & & \\
\hline
\end{tabular}

As this table illustrates, adults use more directives than children. This is predictable, as it is indicative of the adult's authority over the child and the nature of caretaker interaction with children, i.e. they frequently want children to do something. This is probably also connected to the situations that were observed and recorded, such as instances of playing and feeding.

The directive types used most by both adults and children are imperatives and requests. Children use marginally more hints and suggestives than adults. Only adults, as we discussed in section 4.1 use predictions and conditions. This is probably to do with the nature of power differentials in adult and child interaction. While adults are in a position that allows them to promise or make conditions on child behavior, the opposite is generally unseen.

The largest part of the directives in our data (58\%), are imperatives, which is the most used type of directive by both adults (42 tokens) and children (28 tokens). However, there is a difference with regard to addressee. Adults address imperatives to children in all instances. Children address imperatives to a variety of addressees, including playmates, siblings, and adult caretakers. Significantly, in 15 out of the 28 instances of imperatives, i.e. approximately half the time, children address imperatives to adult caretakers. In some instances, they use other types of directives before they use an imperative to the adult. At the same time, we also note the important point that children (except child D) do not use impolite forms of the imperative towards their parents, illustrating that children are well aware of the hierarchies of power in the family network. 
In terms of choice of language, even though all five families claimed to be bilingual in English and Sinhala in the initial interview, none of the families used utterances that were fully in English in the recorded and observed interaction. It was observed that some adults used Sinhala-English mixed utterances. In the case of directives, 08 out of 69 directives included Sinhala-English codeswitching and were used solely by the adults.

$\begin{array}{ll}\text { [17] Mother D: } & \text { give ammi galawala denno } \\ & \text { give mother remove give } \\ & \text { Give, I will remove it and give it back }\end{array}$

Here, the mother starts the utterance in English, with the verb used for the directive in English, and continues the rest of the utterance in Sinhala. Similarly, in other such occasions, the adults use only one English word per utterance (these words are nouns and verbs).

Even though the families had stated they were bilingual, none of the children used English in recorded speech. This aligns with prior findings on bilingual children's speech (see Clark 2009; Matthews 2014) which shows that children are able to discern and decide how to use which language in a context-friendly manner and that they use directives in the language(s) with which they are most familiar. Given that few adults in their environment were using English, the children in this study too use mostly Sinhala.

We had noted that Child D's use of directives is anomalous: she uses twice the number of directives in comparison to other children. She also uses, though only twice, impolite directives to her parents. The recorded speech environment does not show significant differences between child D's environment and that of other children and needs further exploration to fully understand.

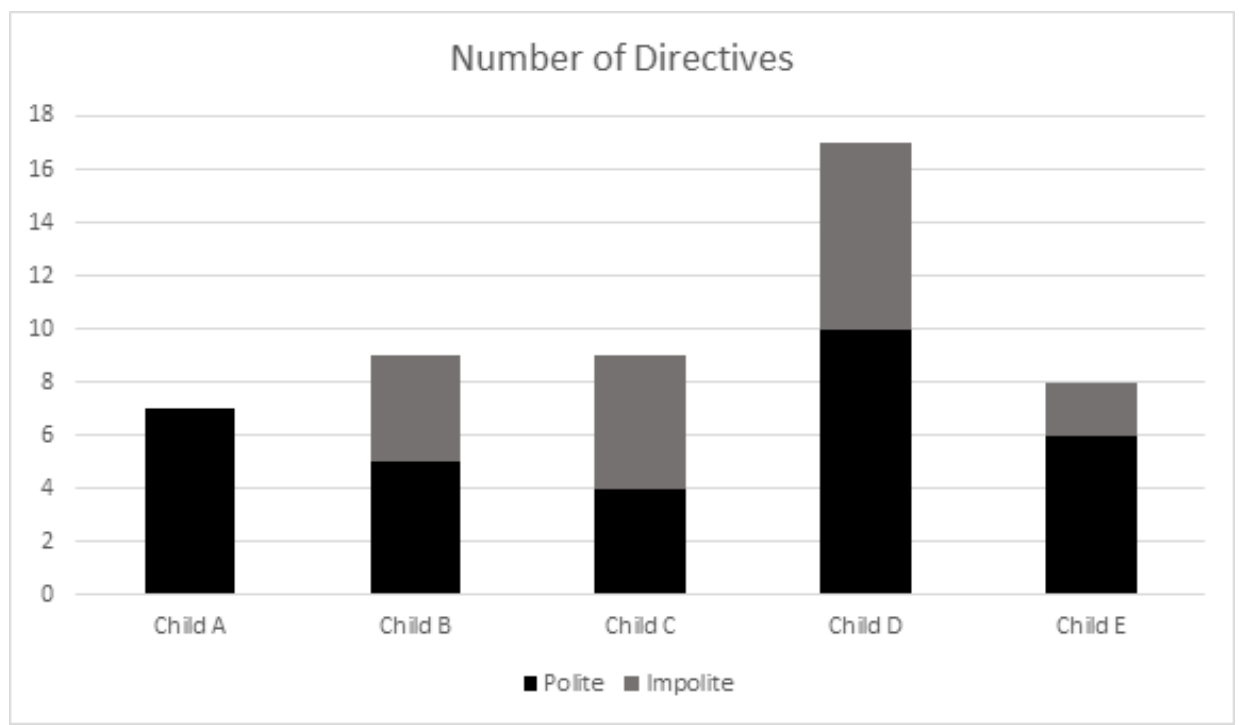

Figure1. Number of polite and impolite directives by child 
Additionally, children address a larger amount of their directives (60\%) to playmates and siblings, of which, roughly half are impolite.

$\begin{array}{rlcc}\text { [18] Child B } & \text { kato } & \text { wahagen } & \text { innowa } \\ & \text { mouth } & \text { shut+COND } & \text { stayIMP } \\ & \text { Shut your mouth and wait. } & \end{array}$

The above is typical of interaction between playmates and is part of their regular communicative style. The child addresses her playmate using an impolite directive because the playmate does not listen to her or does what she asks him to do. While there are studies illustrating that girl children (and women) use more politeness strategies than boy children (or men) (e.g. Ladegaard, 2004; Sheldon, 2016), our data show girl children using a range of polite and impolite linguistic markers. Our findings, therefore, support the literature (Cekaite, 2013; Goodwin, 2006) that argues that children's use of (im)polite linguistic features are as appropriate to their environment, i.e. when interacting with other children, girls may also use 'rough' language.

Very rarely do children use impolite directives towards adult caretakers. Only one child (Child D, twice) uses impolite directives towards parents, and only one child (Child E, 1 directive) uses impolite directives to the grandparent. Even in these situations, the child's use of the impolite imperative generally occurs in situations where they feel that their polite (but insistent) directives are unheeded, showing that this is a marked feature in language use towards adults by children. In most instances, adults ignored the use of the impolite directives by the child towards themselves or others, highlighting an area worth further investigation in language socialization.

\section{Conclusions}

Our study presents findings related to directive use in Sinhala, from the perspective of child language use and adults' child directed speech. These Sinhalaspeaking families showed that children used more directives with their playmates than with adults they address. Furthermore, all the children in this study use similar amounts of polite and impolite directives. However, they use more impolite directives when with playmates and siblings, showing more care when talking to their parents or elderly caregivers (e.g. grandparents). This ties in with prior research in language socialization and pragmatic awareness that children's language use shows heightened awareness of their environment.

At the same time, we note that adults in this study rarely addressed the children's use of the impolite forms. In many instances, adults ignored their use of the impolite form but neither did they praise the use of the polite or canonical form of the directives. We make no conclusions on this phenomenon, given that this was not a focus of our study and is an inadvertent finding. Nevertheless, this would be a useful area for future investigation. In terms of pragmatic awareness, it is worth 
noting that all the children, even when they show developmental errors in phonology, have acquired the pragmatic function of using directives.

Yet, since the study focused mostly on children and child-related activities, we also found less complex forms of directives in our data. The children's directives especially are the more direct and simple forms of the directives. Three forms of directives found in other scholars' data - elliptical directives, epistemic directives and zero verbal directives - are not found in our data; whereas, predictions and conditions are also used as directives in our study. These differences are undoubtedly due to the specific linguistic and research context of our study, highlighting the importance of context to pragmatic research. Sinhala's linguistic resources may be more suitable for some types of directives, given that the findings of both our study and Fedricks (2012) differ to Ervin-Tripp's classification of English directives. More research is necessary in both Sinhala and other languages with different linguistic properties to English, to move towards a general classification of directives.

\section{Acknowledgements}

Initial versions of this study were presented by the first author at the Undergraduate Research Symposium (2016), Dept of English Language Teaching, University of Kelaniya and at the International Conference of the Sri Lanka English Language Teachers' Association (2016). A co-authored preliminary analysis of the current version of the study was presented at the Sinhala Studies Symposium (2018) at the University of Colombo, Sri Lanka. The authors wish to acknowledge the useful comments by participants of these conferences and the constructive feedback by two anonymous reviewers.

\section{References}

Aronsson, K., \& Thorell, M. (1999). Family politics in children's play directives. Journal of Pragmatics, 31(1), 25-48. https://doi.org/10.1016/S03782166(98)00050-2

Brown, P., \& Levinson, S. C. (1987). Politeness: Some universals in language usage. In A. Jaworski \& N. Coupland (Eds.), The Discourse Reader (pp. 311-323). London \& New York: Routledge.

Byon, A. S. (2006). The role of linguistic indirectness and honorifics in achieving linguistic politeness in Korean requests. Journal of Politeness Research, 2(2), 247-276. https://doi.org/10.1515/PR.2006.013

Cameron-Faulkner, T. (2014). The development of speech acts. In D. Matthews (Ed.), Pragmatic Development in First Language Acquisition (pp. 37-52). Amsterdam / Philadelphia: John Benjamins.

Cekaite, A. (2013). Child Pragmatic Development. In The Encyclopedia of Applied Linguistics (pp. 1-7). Blackwell Publishing Ltd. https://doi.org/10.1002/9781405198431.wbeal0127 
Ch. Premawardhena, N. (2007). The unwritten rules in a language: An analysis of spoken Sinhala. In M. Grein \& E. Weigand (Eds.), Dialogue and culture (pp. 213-225). Amsterdam: John Benjamins.

Chandralal, D. (2010). Sinhala. Amsterdam: John Benjamins Publishing.

Clark, E. V. (2009). First Language Acquisition. Cambridge University Press.

Craven, A., \& Potter, J. (2010). Directives: Entitlement and contingency in action. Discourse Studies, 12, 419-422. https://doi.org/10.1177/1461445610370126

Curl, T. S., \& Drew, P. (2008). Contingency and Action: A Comparison of Two Forms of Requesting. Research on Language \& Social Interaction, 41(2), 129153. https://doi.org/10.1080/08351810802028613

Duranti, A., Ochs, E., \& Schieffelin, B. B. (Eds.). (2012). The Handbook of Language Socialization. Malden, MA: Wiley-Blackwell.

Economidou-Kogetsidis, M. (2002). Requesting strategies in English and Greek: Observations from an airline's call centre. Nottingham Linguistic Circular, 17, 17-32. Retrieved from https://www.nottingham.ac.uk/research/groups/cral/documents/nlc/nlc2000-2004/nlc-volume17-2002.pdf\#page $=21$

Ervin-Tripp, S. (1976). Is Sybil there? the structure of some American English directives. Language in Society, 5(1), 25-66. https://doi.org/10.1017/S0047404500006849

Fedricks, K. (2012). Directives in Sinhala: An investigation of directive use in a Buddhist temple setting. California State University, Long Beach. Retrieved from

http://search.proquest.com/openview/27370f39085736b9ff539962f79e7e50/ 1 ?pq-origsite $=$ gscholar $\& \mathrm{cbl}=18750 \&$ diss $=\mathrm{y}$

Ferguson, C. A., \& Farwell, C. B. (1975). Words and sounds in early language acquisition. Language, 51(2), 419-439. https://doi.org/10.1017/CBO9780511980503.007

Gair, J., Lust, B., Sumangala, L., \& Rodrigo, M. (1998). Acquisition of Null Subjects and Control in Some Sinhala Adverbial Clauses. In Studies in South Asian Linguistics: Sinhala and Other South Asian Languages (pp. 271-285).

Gair, J. W., \& Paolillo, J. C. (1997). Sinhala. München \& Newcastle: LINCOM EUROPA.

Geyer, N. (2018). Directives in Japanese Workplace Discourse. In Japanese at Work (pp. 177-203). Cham: Springer International Publishing. https://doi.org/10.1007/978-3-319-63549-1_8

Goodwin, M. (2006). The Hidden Life of Girls: Games of stance, status, and exclusion. Blackwell Publishing Ltd.

Hettiarachchi, S., \& Ranaweera, M. (2013). 'Story Boxes": Using a Multisensory Story Approach to Develop Vocabulary in Children Experiencing LanguageLearning Difficulties.' International Journal for Cross-Disciplinary Subjects in 
Education (IJCDSE), 4(1), 1076-1081.

Hollos, M., \& Beeman, W. (1978). The development of directives among Norwegian and Hungarian children: An example of communicative style in culture. Language in Society, 7(3), 345-355. https://doi.org/10.1017/S0047404500005765

Küntay, A. C., Nakamura, K., \& Şen, B. A. (2014). Crosslinguistic and crosscultural approaches to pragmatic development. In D. Matthews (Ed.), Pragmatic Development in First Language Acquisition (pp. 317-341). Amsterdam / Philadelphia: John Benjamins.

Ladegaard, H. J. (2004). Politeness in young children's speech: context, peer group influence and pragmatic competence. Journal of Pragmatics, 36, 20032022. https://doi.org/10.1016/j.pragma.2003.11.008

MacNamara, J. (1972). Cognitive basis of language learning in infants. Psychological Review, 79(1), 1-13. Retrieved from http://dx.doi.org/10.1037/h0031901

Matthews, D. (Ed.). (2014). Pragmatic Development in First Language Acquisition. Amsterdam/Philadelphia: John Benjamins Publishing.

Rossi, G. (2012). Bilateral and Unilateral Requests: The Use of Imperatives and Mi X? Interrogatives in Italian. Discourse Processes, 49(5), 426-458. https: / / doi.org/ 10.1080/0163853X.2012.684136

Searle, J. R. (1975). A Taxonomy of Illocutionary Acts. Minneapolis: The University of Minnesota Digital Conservancy.

Sheldon, A. (2016). Pickle fights: Gendered talk in preschool disputes Pickle Fights : Gendered Talk in Preschool Disputes. Discourse Processes, 13(1), 5-31. https://doi.org/10.1080/01638539009544745

Silva, H. de. (2002). Ages and stages of the acquisition of casemarkers in Sinhala. University College London.

Takada, A. (2013). Generating morality in directive sequences: Distinctive strategies for developing communicative competence in Japanese caregiver-child interactions. Language \& Communication2, 33(4), 420-438. Retrieved from https://www.sciencedirect.com/science/article/pii/S027153091300027X

Wardhaugh, R. (2011). An Introduction to Sociolinguistics. West Sussex: WileyBlackwell.

Weigel, M. M. \& Weigel, R. M. (1985). Directive Use in a Migrant Agricultural Community: A Test of Ervin-Tripp's Hypotheses. Language in Society, 14(1), 63-79. Retrieved from https://www.jstor.org/stable/4167604

Zufferey, S. (2016). Pragmatic Acquisition. In J.-O. Östman \& J. Verschueren (Eds.), Handbook of Pragmatics. Amsterdam: John Benjamins. https://doi.org/10.1075/hop.20.pra5 